Counsellia: Jurnal Bimbingan dan Konseling, 9 (2), 2019 | 89-102

Copyright (C2019 Universitas PGRI Madiun

ISSN: 2088-3072 (Print) / 2477-5886 (Online)

Available online at: http://e-journal.unipma.ac.id/index.php/JBK

DOI: $10.25273 /$ counsellia.v9i2.4618

\title{
Keefektifan Solution Focused Brief Counseling (SFBC) untuk menurunkan perilaku prokrastinasi akademik Siswa
}

\author{
Kristiyaningrum Tri Kusumawide ${ }^{1}$, Wahyu Nanda Eka Saputra ${ }^{2}$, Said Alhadi ${ }^{3}$, Hardi \\ Prasetiawan $^{4}$ \\ ${ }^{1}$ FKIP, Universitas Ahmad Dahlan, Yogyakarta \\ kristiyaningrum1500001137@ webmail.uad.ac.id \\ ${ }^{2}$ FKIP, Universitas Ahmad Dahlan, Yogyakarta \\ wahyu.saputra@bk.uad.ac.id \\ ${ }^{3}$ FKIP, Universitas Ahmad Dahlan, Yogyakarta \\ said.alhadi@bk.uad.ac.id \\ ${ }^{4}$ FKIP, Universitas Ahmad Dahlan, Yogyakarta \\ hardi.Prasetiawan@bk.uad.ac.id
}

\begin{abstract}
Abstrak
Penelitian ini bertujuan untuk mengetahui keefektifan solution focused brief counseling (SFBC) untuk menurunkan perilaku prokrastinasi akademik siswa di kelas khusus olahraga SMP Negeri 2 Galur Kulon Progo. Jenis penelitian yang digunaan adalah Eskperimen dengan desain penelitian PreEksperimental Design menggunakan model One group pretest posttest design. Penentuan subjek menggunakan teknik non probability sampling design dengan purposive sampling. Subjek penelitian adalah siswa kelas khusus olahraga SMP Negeri 2 Galur Kulon Progo. Berdasarkan hasil penelitian dapat disimpulkan bahwa ada perbedaan signifikan antara tingkat prokrastinasi akademik siswa sebelum dan sesudah diberikan layanan solution focused brief counseling (SFBC).
\end{abstract}

Kata kunci: prokrastinasi akademik, solution focused brief counseling

\begin{abstract}
This study aims to determine the effectiveness of "solution focused brief counseling $(S F B C)$ " to reduce the behavior of academic procrastination of students in the special sports class at Galur Negeri 2 Kulon Progo. Experiment with Pre-Experimental Design research design using One group pretest posttest design. Subjects are determined by using non probability sampling design with purposive sampling. The subjects of the study were students of the special sport class of JHS Negeri 2 Galur Kulon Progo. Based on the results of the study, it can be concluded that there are significant differences level of student academic procrastination between before and after being given solution services focused brief counseling $(S F B C)$.
\end{abstract}

Keyword: academic procrastination, solution focused brief counseling 


\section{PENDAHULUAN}

Belajar dan pembelajaran adalah suatu kegiatan yang tidak pernah terpisahkan dari kehidupan manusia, khususnya bagi seorang siswa yang sedang menikmati masa belajarnya. Belajar dan pembelajaran dikatakan berhasil serta berkualitas apabila siswa terlibat secara aktif, baik fisik, mental maupun sosial pada proses pembelajaran. Berhasil atau tidaknya proses belajar dan pembelajaran juga dapat mempengaruhi kesuksesan akademik siswa.

Kesuksesan akademik merupakan variabel penting bagi siswa. Tolok ukur keberhasilan atau tidaknya individu dalam menjalankan seluruh kegiatan belajar bisa disebut dengan kesuksesan akademik. Terdapat dua bentuk aspek kesuksesan akademik yaitu kualitatif dan kuantitatif. Di dalam aspek kualitatif mempunyai kepribadian, motivasi belajar, kepercayaan diri, penyesuaian diri dan integritas yang baik. Namun, pada aspek kuantitatif terdapat hasil nilai pelajaran, rapor, ujian nasional atau indeks prestasi kumulatif yang tinggi (Yusak, 2014). Untuk menunjang kesuksesan akademik diperluan satu upaya bagi para siswa misalnya dalam kedisiplinan mereka dalam hal tanggung jawabnya selama di sekolah yaitu kegiatan belajar.

Sikap tanggung jawab yang harus dimiliki siswa adalah tanggung jawab terhadap tugas dan kewajiban sekolah. Dalam hal ini adalah tidak menunda mengerjakan tugas merupakan salah satu bukti siswa yang bertanggung jawab. Orang yang melakukan penundaan dalam mengerjakan tugas bisa disebut dengan prokrastinasi akademik. Prokrastinasi akademik adalah suka menunda-nunda dalam menyelesaikan tugas atau suatu pekerjaan yang dilakukan secara berulang. Penundaan ini pada dasarnya dilakukan dengan sengaja meskipun siswa tersebut mengetahui dampak negatif yang akan terjadi. Faktanya, masih terdapat siswa yang mengalami masalah dalam mengerjakan tugas-tugas akademik yaitu penundaan dalam menyelesaikan atau memulai untuk mengerjakan tugas bisa disebut dengan prokrastinasi akademik.

Prokrastinasi dapat di golongkan menjadi dua bentuk yaitu functional procrastination dan disfunctional procrastination. Functional procrastination adalah perilaku penundaan yang memiliki tujuan, misalnya seseorang yang membayar pajak untuk dibayaran khusus pada tanggal tertentu. Disfunctional procrastination adalah perilaku penundaan yang tidak memiliki tujuan, misalnya dengan melakukan perbuatan yang negatif daripada mengerjakan tugas yang seharusnya bisa di selesaikan jauh-jauh hari (Ferrari, Johnson, \& McCown, 1995). Pada penelitian ini, bentuk 
prokrastinasi yang diteliti adalah disfunctional procrastination.

Prokrastinasi akademik dari tahun ke tahun seakan-akan tidak ada habisnya, hal ini dibuktikan dengan penelitian yang telah dilakukan oleh Ellis dan Knauss tahun 1977 terdapat $70 \%$ mahasiswa dari Universitas di Amerika telah melakukan prokrastinasi akademik (Knaus, 2002). Dari realita yang telah di paparkan tadi juga diperkuat dengan hasil penelitian yang dilakukan Solomon dan Rothblum tentang prokrastinasi akademik bahwa mahasiswa melakukan prokrastinasi akademik secara bervariasi terhadap tugas akademik antara lain prokrastinasi akademik terhadap tugas menulis, belajar untuk kesiapan ujian, tugas membaca, tugas administratif, prokrastinasi dalam menghadiri perkuliahan, dan prokrastinasi terhadap aktivitas perkuliahan secara umum (Fauziah, 2015). Selain itu hasil penelitian yang di lakukan di SMP Muhammadiyah 9 Yogyakarta menunjukan bahwa 17,3\% memiliki prokrastinasi akademik tinggi, $77,1 \%$ sedang dan $5,7 \%$ rendah (Munawaroh, Alhadi, \& Saputra, 2017).

Hasil studi pendahuluan yang telah dilakukan peneliti di kelas VII SMP N 2 Galur Kulon Progo mendapatkan hasil bahwa 1,5\% memiliki prokrastinasi akademik tinggi, $81,8 \%$ memiliki prokrastinasi akademik sedang dan $16,67 \%$ memiliki prokrastinasi akademik rendah. Hasil studi pendahuluan tersebut diperkuat dengan hasil wawancara oleh guru BK SMP N 2 Galur Kulon Progo yang mengatakan bahwa siswa sering melakukan prokrastinasi akademik, biasanya tugas di kerjakan semalam sebelum tugas itu di kumpulkan yang membuat hasil dari tugas tersebut tidak maksimal.

Prokrastinasi dapat terjadi disebabkan karena batas waktu pengumpulan tugas yang lumayan lama sehingga siswa memiliki rasa malas untuk mengerjakan tugas, bermain, atau bahkan mengerjakan tugas sesuai dengan mood yang sedang dirasakannya. Adapun karakteristik prokrastinasi akademik dapat ditinjau dari aspek kepribadian dan prestasi dari Big Five Theory yaitu ada lima faktor, antara lain: Neurotisisme, Opennes to Experience, Agreeableness, Extrovert, dan Conscientiousness (Ghufron \& Risnawita, 2010). Selain itu, siswa terkadang memiliki persepsi bahwa tugas yang diberikan terlalu sulit karena siswa tidak paham dengan materi dan tugas yang diberikan oleh guru, masih bergantung dengan bantuan dari teman, dan yang terakhir siswa lebih mementingkan kegiatan diluar sekolah daripada mengerjakan tugas.

Siswa lebih mementingkan kegiatan di luar kelas, misalnya organisasi, ekstrakulikuler, bermain dan kegiatan lainnya. Hal tersebut 
mengakibatkan tubuh menjadi lelah dan tidak memanfaatkan waktu dengan baik, sehingga ketika kembali ke rumah tugas yang seharusnya dikerjakan sering kali di lupakan. Masalah tersebut menandakan bahwa siswa tidak maksimal dalam mencapai prestasi belajar yang akan mengakibakan prestasi hasil belajar siswa menurun.

Perilaku siswa tersebut pada hakikatnya dapat berdampak pada beberapa yaitu aspek sosial, psikologis, maupun akademik. Jia dilihat dari dari aspek sosial kemungkinan siswa tidak mendapatkan simpati dari orang lain atau temannya sendiri dan dijauhkan dari interaksi pergaulan. Kemudian, jika dilihat dari aspek psikologis perilaku penundaan atau prokrastinasi bisa sangat mengganggu aktivitas belajar dan kinerja untuk mencapai tujuan pembelajaran (Ernawati \& Sumarwoto, 2016). Perilaku prokrastinasi akademik dapat menghambat mewujudkan prestasi di sekolah. Hal tersebut dapat dibuktikan dengan penelitian sebelumnya bahwa prokrastinasi akademik berhubungan negatif dengan prestasi akademik (Oematan, 2013). Banyak juga penelitian mengemukakan bahwa prokrastinasi berhubungan dengan nilai rata-rata yang lebih rendah, kinerja pada tugas lebih rendah lebih, dan prestasi di kelas yang lebih rendah (Ackerman \& Gross, 2005).
Prestasi akademik yang dimiliki siswa pastinya tidak terlepas dari kinerja yang dimiliki siswa tersebut. Namun, akibat dari prokrastinasi akademik menyebabkan kinerja siswa dalam hal akademik berkurang, dengan mutu kehidupan individu yang berkurang dan menurunnya prestasi akademik siswa (Ferrari dkk., 1995). Hasil penelitian menyebutan bahwa terdapat hubungan yang signifikan antara prokrastinasi dan kinerja, prokrastinasi dan kepuasan kehidupan, kinerja dan kepuasan hidup yang tidak ada efek interaktif yang ditemukan antara prokrastinasi, kinerja dan kepuasan hidup (Savithri, 2014)

Kebiasaan menunda melakukan sesuatu terutama dalam penyelesaian tugas akademik dapat mempengaruhi kesuksesan dan kegagalan individu. Jika, fenomena ini tidak ditanggapi dengan serius akan berdampak negatif bagi prestasi siswa serta masa depan siswa tersebut. Oleh karena hal tersebut guru di sekolah harus mempunyai tanggung jawab yang sangat besar untuk membantu siswa keluar dari masalah perilaku penundaan dalam mengerjakan tugas atau prokrastinasi akademik, termasuk guru bimbingan dan konseling (Munawaroh dkk., 2017). Keberadaan guru BK sangatlah penting karena guru BK memiliki kualitas kepribadian dan kemampuan yang baik serta memiliki pengetahuan keahlian profesional 
tentang layanan bimbingan dan konseling. Peran dari guru BK yaitu memberikan bantuan kepada siswa yang membutuhkan bimbingan untuk mengembangan potensipotensi siswa sesuai dengan tugas dan norma guru BK.

Maka dari itu, untuk menurunkan perilaku penundaan atau prokrastinasi akademik serta dapat mempunyai dampak yang lebih positif pada pola belajar atau hasil belajar siswa perlu adanya bantuan guru BK maupun intervensi yang diberikan agar tujuan tersebut tercapai. Salah satu cara mengatasi prokrastinasi akademik dengan menerapkan Solution Focused Brief Counseling ( $S F B C$ ). Sesuai dengan hasil penelitian sebelumnya merekomendasikan bahwa dapat menggunakan konseling ringkas berfokus solusi untuk mereduksi perilaku prokrastinasi akademik siswa (Munawaroh dkk., 2017). Solution Focused Brief Counseling (SFBC) ini juga sering disebut sebagai Constructivist Therapy, Solution Focused Therapy, dan Solution Focused Brief Counseling (Sumarwiyah, Zamroni, \& Hidayati, 2015).

Konseling Singkat Berfokus Solusi (Solution Focused Brief Therapy/SFBT) adalah salah satu pendekatan konseling yang mempunyai konsep sederhana dan sangat mudah untuk dipraktikan karena lebih fokus membicarakan bagaimana mencari solusi daripada membicaraan tentang permasalahan siswa. Hasil penelitian sebelumnya konseling singkat berfokus solusi berdampak pada perubahan terapeutik untuk peningkatan harga diri (Rusandi \& Rachman, 2014). Temuan penelitian sebelumnya juga menunjukan bahwa pemberian treatment solution focused brief therapy sebagai teknik bimbingan dan konseling Islam efektif untuk menurunkan prokrastinasi akademik mahasiswa STAIS Majenang (Fernando \& Rahman, 2018).

Perilaku prokrastinasi akademik memilih mengerjakan tugas akademiknya dibatas akhir pengumpulan tugas sehingga menimbulkan perasaan tidak nyaman, keterlambatan dan kegagalan dalam menyelesaikan tugas akademiknya. Artinya sebagian besar perilaku prokrastinasi akademik disebabkan oleh self regulation yang rendah. Diperkuat dengan pendapat ahli bahwa siswa yang melakukan prokrastinasi akademik mengalami self regulation atau pengelolaan diri dan kemampuan manajemen diri yang rendah (Solomon \& Rothblum, 1984). Prokrastinasi melibatkan gangguan dalam kemampuan mengatur pikiran dan upaya untuk mencapai tujuan jangka panjang.

Siswa yang tidak bisa mengatur perilaku mereka akan menunggu sampai menit terakhir untuk memulai menyelesaikan tugas akademik karena hanya dengan begitu mereka 
akan merasakan tekanan untuk bertindak. Sebaliknya, jika siswa bisa mengatur perilakunya siswa lebih suka didukung daripada ditekan dan dapat diharapkan lebih tepat waktu, bahkan ketika kegiatan tersebut tidak menyenangkan (Senecal, Koestner, \& Vallerand, 1995). Salah satu fungsi bimbingan dan konseling di sekolah adalah pengentasan perilaku prokrastinasi akademik. Melalui pendekatan Solution Focused Brief Counseling (SFBC) yang merupakan bentuk konseling singkat diberikan kepada siswa dengan membantu memunculkan dan mengkontruksikan solusi pada masalah yang sedang dihadapi.

Berdasarkan beberapa uraian tersebut, peneliti tertarik untuk memberikan bantuan pemecahan masalah prokrastinasi akademik pada siswa. Asumsi peneliti, siswa mengalami perilaku prokrastinasi akademik akan berubah apabila diberikan layanan konseling individual dengan SFBC. Atas asumsi tersebut maka peneliti tertarik untuk melakukan penelitian dengan judul "Keefektifan Solution Focused Brief Counseling (SFBC) untuk Menurunkan Perilaku Prokrastinasi Akademik Siswa di Kelas Khusus Olahraga SMP Negeri 2 Galur Kulon Progo". Alasan peneliti melakukan penelitian di Kelas Khusus Olahraga SMP Negeri 2 Galur Kulon Progo, karena pada kelas khusus olahraga berbeda dengan kelas reguler yang lebih banyak kegiatan olahraga. Kegiatan olahraga yang terlalu padat akan menimbulkan kelelahan dan kejenuhan. Sehingga mengakibatkan siswa melakukan prokrastinasi akademik atau penundaan dalam menyelesaikan tugas. Penelitian ini bertujuan untuk mengetahui keefektifan solution focused brief counseling (SFBC) untuk menurunkan perilaku prokrastinasi akademik siswa di kelas khusus olahraga SMP Negeri 2 Galur Kulon Progo

\section{METODE PENELITIAN \\ Rancangan Penelitian}

Penelitian ini menggunakan pendekatan penelitian kuantitatif dengan desain penelitian eksperimen untuk melihat keefektifan SFBC untuk menurunkan prokrastinasi akademik siswa kelas VII kelas khusus olahraga di SMP 2 Galur Kulon Progo. Bentuk desain penelitian yang akan digunakan adalah pre-experimental design dengan menggunakan model one group pretest posttest.

\section{Instrumen Penelitian}

Penelitian ini menggunakan 2 (dua) instrumen yaitu skala prokrastinasi akademik dan pedoman observasi. Skala prokrastinasi akademik terdiri dari 36 pernyataan yang sudah tervalidasi. Dengan nilai koefisien alpha cornbach pada penelitian ini adalah 0,891, maka dapat disimpulkan bahwa termasuk 
dalam kategori reliabilitas tinggi. Pedoman observasi digunakan setelah pelaksanaan treatment dan posttest telah selesai. Lembar pedoman observasi juga dibuat sesuai dengan indikator pada prokrastinasi akademik.

\section{Prosedur Pengumpulan Data}

Pada penelitian ini peneliti mengadopsi skala prokrastinasi akademik milik Wahyu Nanda Eka Saputra, M Pd., Kons. dan sudah teruji validitas dan reliabilitasnya (Saputra, 2015) yang kemudian disebaran pada siswa kelas khusus olahraga SMP Negeri 2 Galur ulon Progo.

\section{Teknik Analisis Data}

Penelitian ini memilih data yang relevan dan data yang ditetapkan sebagai jawaban dari subjek penelitian yang dapat menggambarkan tingginya perilaku prorastinasi akademik siswa kelas VII Kelas Khusus Olahraga SMP N 2 Galur Kulon Progo. Data penelitian ini terkumpul dalam bentuk angka sehingga analisis menggunaan statistik. Statistik yang digunakan untuk analisis data dalam penelitian ini menggunakan statistik inferensial. Penggunaan analisis data statistik pada penelitian ini menggunakan rumus t-test dengan bantuan program Statistical Package For Social Sciens (SPSS) versi 16.0 untuk mencari tingkat penurunan perilaku prokrastinasi akademik siswa.

\section{HASIL DAN PEMBAHASAN \\ Hasil}

Hasil penelitian ini menjelaskan dua bagian yaitu penurunan nilai dari hasil penyebaran skala prokrastinasi akademik antara pretest ke posttest serta hasil uji signifikansi dengan menggunakan rumus $t$-test.

Penurunan Nilai Pretest ke Posttest

Data dari hasil pretest dan posttest mengenai perilaku prokrastinasi akademik selanjutnya diolah menggunakan microsoft excel. Hasil pretest dan posttest skala prokrastinasi akademik siswa kelas khusus olahraga SMP Negeri 2 Galur Kulon Progo adalah sebagai berikut:

Tabel 1. Deskripsi Skor Prokrastinasi Akademik Siswa Kelas Khusus Olahraga

\begin{tabular}{|c|cccccc}
\multirow{2}{*}{ No } & \multirow{2}{*}{ Subjek } & \multicolumn{3}{c}{ Skor dan Kategori } & Gain \\
\cline { 3 - 6 } & & \multicolumn{2}{c}{ Pretest } & \multicolumn{2}{c}{ Posttest } & $(\mathrm{d})$ \\
\hline 1 & GFW & 113 & Tinggi & 75 & Sedang & 38 \\
\hline 2 & QNT & 122 & Tinggi & 46 & Rendah & 76 \\
\hline 3 & SOR & 115 & Tinggi & 69 & Rendah & 46 \\
\hline Total & N $=3$ & 350 & & 190 & & $\sum \mathrm{d}=160$ \\
\hline Mean & & 116,7 & & 63,33 & & 53,33 \\
\hline
\end{tabular}

Pada tabel di atas dapat dijelaskan bahwa terjadi penurunan perilaku prokrastinasi akademik siswa dari yang berada pada kategori tinggi menurun menjadi kategori sedang dan rendah. Sebelum treatment diberikan, skor rata-rata prokrastinasi akademik siswa yaitu 
116,7 sedangkan setelah diberikan treatment skor rata-rata prokrastinasi akademik siswa kelas khusus olahraga SMP N 2 Galur Kulon Progo menjadi 63,33. Maka dari hasil pretest dan posttest yang telah dilakukan oleh konseli terjadi penurunan dengan skor rata-rata sebesar 53,33. Hasil penelitian ini juga menunjukan bahwa penurunan perilaku prokrastinasi akademik siswa kelas khusus olahraga yang paling signifikan adalah pada subjek QNT dengan skor sebesar 46. Sedangkan penurunan skor prokrastinasi akademik yang paling besar yaitu pada subjek GFW dengan skor sebesar 75 .

Secara visual penurunan prokrastinasi akademik siswa kelas khusus olahraga SMP Negeri 2 Galur Kulon Progo dapat dilihat pada grafik berikut ini:

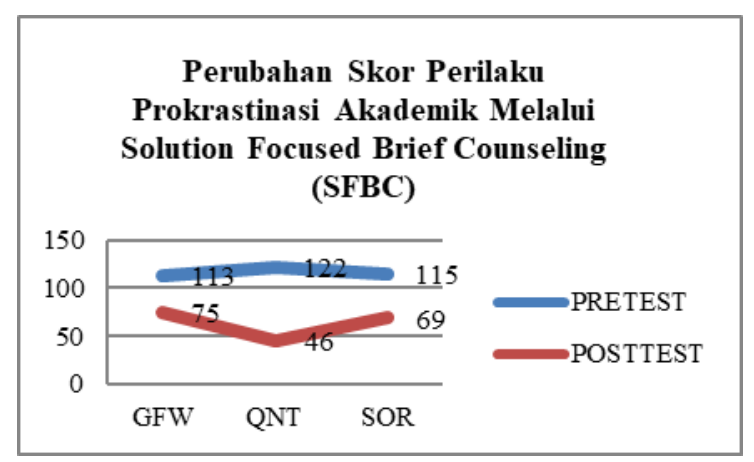

Gambar 1. Perubahan Skor Perilaku Prokrastinasi Akademik Melalui Konseling Individu dengan Solution Focused Brief Counseling (SFBC)

Berdasarkan gambar grafik di atas dapat diketahui bahwa terjadi penurunan perilaku prokrastinasi akademik siswa setelah mengikuti layanan dengan solution focused brief counseling (SFBC). Hal ini dapat dilihat dari grafik posttest yang berwarna merah lebih rendah dari grafik pretest yang berwarna biru. Oleh karena itu, berdasakan gambar grafik tersebut dapat ditarik kesimpulan bahwa terdapat penurunan skor prokrastinasi akademik siswa setelah dilakukannya layanan dengan pendekatan solution focused brief counseling (SFBC).

\section{Hasil Uji Signifikansi}

Pada derajat bebas $(\mathrm{db})=\mathrm{n}-1=$ $3-1=2$ dengan taraf signifikansi $(\alpha)=5 \%$ nilai $\mathrm{t}_{\text {tabel }}=2,919$ sehingga Ho ditolak jika nilai $\mathrm{t}$ hitung $>\mathrm{t}$ tabel $(2,919)$ dan Ho diterima jika nilai t hitung $\leq 2,919$. Berikut adalah tabel hasil perhitungan nilai $\mathrm{t}$ hitung dengan menggunakan bantuan SPSS. 
Tabel 2. Hasil Penilaian t-hitung Paired Sample Test

\begin{tabular}{|c|c|c|c|c|c|c|c|c|c|}
\hline & \multicolumn{5}{|c|}{ Paired Differences } & \multirow{3}{*}{$\mathrm{T}$} & \multirow{3}{*}{$\mathrm{df}$} & \multirow{3}{*}{$\begin{array}{l}\text { Sig. (2- } \\
\text { tailed) }\end{array}$} & \\
\hline & \multirow[t]{2}{*}{ Mean } & \multirow[t]{2}{*}{$\begin{array}{c}\text { Std. } \\
\text { Deviation }\end{array}$} & \multirow[t]{2}{*}{$\begin{array}{l}\text { Std. } \\
\text { Error } \\
\text { Mean }\end{array}$} & \multicolumn{2}{|c|}{$\begin{array}{l}\text { 95\% Confidence } \\
\text { Interval of the } \\
\text { Difference }\end{array}$} & & & & \\
\hline & & & & Lower & Upper & & & & \\
\hline Pair 1 & $\begin{array}{l}\text { Pretest - } \\
\text { Posttest }\end{array}$ & 5.3333E1 & $\begin{array}{c}15.502 \\
69\end{array}$ & 8.95048 & 14.82252 & 91.84415 & 5.959 & 2 & .027 \\
\hline
\end{tabular}

Berdasarkan pada perhitungan di atas diperoleh nilai $t_{\text {hitung }}=5,959$ $>2,919\left(\mathrm{t}_{\text {tabel }}\right)$ pada taraf signifikansi $(\alpha)=5 \%$ sehingga Ho ditolak yang menunjukan bahwa ada penurunan perilaku prokrastinasi akademik siswa yang signifikan setelah diberikan solution focused brief counseling $(S F B C)$ pada siswa kelas olahraga SMP Negeri 2 Galur Kulon Progo. Oleh karena itu, hipotesis penelitian yang berbunyi: "solution focused brief counseling (SFBC) efektif untuk menurunkan perilaku prokrastinasi akademik siswa kelas khusus olahraga SMP Negeri 2 Galur Kulon Progo" teruji kebenarannya.

\section{PEMBAHASAN}

Hasil penelitian ini menyimpulkan bahwa solution focused brief counseling (SFBC) efektif dan dapat dijadikan sebagai alternatif bantuan untuk menurunkan perilaku prokrastinasi akademik. Solution Focused Brief Counseling (SFBC) merupakan salah satu intervensi yang dapat digunakan oleh guru BK untuk menurunkan perilaku prokrastinasi akademik siswa. Pendekatan ini sebenarnya juga percaya bahwa setiap individu memiliki solusinya sendiri untuk permasalahan individu tersebut, akan tetapi terkadang mereka lupa dengan potensi yang dimiliki karena selalu memandang masalahnya (Corey, 2015). Hal tersebut sesuai dengan keadaan individu yang memiliki perilaku prokrastinasi akademik tinggi, yang menganggap bahwa perilaku penundaan atau prokrastinasi akademik adalah sesuatu hal yang wajar. Akan tetapi perilaku tersebut dilakukan dalam keadaan sadar dan berdampak pada aspek akademiknya. Namun tidak kunjung mencoba untuk mencari solusi akan masalahnya tersebut. SFBC ini diberikan pada siswa yang memiliki prokrastinasi akademik yang percaya bahwa dengan perubahan yang berkesinambungan akan membuat siswa mampu menurunkan tingkat prokrastinasi akademik.

Penelitian yang telah dilakukan sebelumnya juga membuktikan bahwa konseling singkat berfous solusi dapat secara efektif meningkatkan self esteem pada mahasiswa (Rusandi \& Rachman, 2014). Penelitian sebelumnya ini menggunakan rancangan penelitian 
quasi experimental design dengan subjek mahasiswa FKIP UNLAM Banjarmasin. Dengan teknik pengumpulan data Rosenberg's Self Esteem Scale (RSES). Hasil dari penelitian tersebut ditemukan bahwa ada perbedaan tingkat harga diri ketika mahasiswa sebelum mendapatan konseling singkat berfokus solusi dan sesudah mendapatkan konseling singkat berfous solusi. Penelitian tersebut mengambil objek harga diri atau self esteem sedangkan pada penelitian ini mengambil objek prokrastinasi akademik. Kemudian, penelitian tersebut hanya melakukan emphatic listening. Namun, pada penelitian ini menggunaan beberapa teknik yaitu scalling question, miracle question dan exception question dalam treatmennya, penelitian ini juga dilakukan dengan lima kali pertemuan.

Penelitian lain juga menyatakan bahwa konseling singkat berfokus solusi efektif untuk meningkatkan motivasi berprestasi siswa SMK (Wiyono, 2015). Penelitian tersebut juga sama-sama dengan penelitian ini yang menggunakan desain penelitian eksperimen, akan tetapi berbeda bentuk desain penelitian. Jika penelitian ini menggunakan bentuk desain one group pretest posttest, penelitian tersebut menggunakan bentuk desain pretest \& posttest control group design. Subjek dalam penelitian tersebut menggunakan 10 siswa kelas $\mathrm{X}$
SMK Mambaul Ulum Bata-Bata Pemekasan, namun pada penelitian ini subjek penelitian menggunakan 3 siswa kelas VI kelas khusus olahraga SMP Negeri 2 Galur Kulon Progo. Hasil penelitian yang dilakukan oleh Wiyono menunjukan bahwa pendekatan konseling singkat berfokus solusi terbuti efektif untuk meningkatkan motivasi belajar siswa SMK. Hasil analisis menunjukan bahwa kelima konseli pada kelompok eksperimen mengalami peningkatan motivasi berprestasi lebih tinggi dibandingkan kelompok kontrol. Penelitian dari Wiyono terfokus pada motivasi berprestasi sedangkan penelitian ini terfokus pada prokrastinasi akademik.

Sejalan dengan penelitian lain yang membutikan bahwa konsep bimbingan dan konseling islam solution focused brief therapy (SFBT) untuk membantu menyembuhan perilaku prokrastinasi mahasiswa (Fernando \& Rahman, 2016). Penelitian milik Fernando \& Rahman ini menggunakan konseling berbasis islami yang dikombinasi dengan pendekatan solution focused brief therapy (SFBT), namun penelitian ini hanya fokus pada pendekatan SFBC dan tidak dikombinasikan dengan konseling islami. Tahapan yang digunakan dalam penelitian tersebut juga berbeda dengan penelitian ini, pasalnya pada tahapan yang digunakan kurang rinci dan yang 
terkesan mencampuradukkan antara teknik dengan tahapan.

Solution Focused Brief Therapy (SFBT) efektif untuk meningkatkan keterbukaan diri pada siswa (Fadilah, 2015). Penelitian tersebut menggunakan one group pretest posttest design dengan subjek penelitian berjumlah 5 siswa kelas VIII D SMP Negeri 1 Prambon yang mempunyai keterbukaan rendah. Metode pengumpulan data yang digunakan penelitian dari Fadilah adalah angket tertutup, sedangkan penelitian ini menggunakan skala. Pada penelitian Fadilah fokus pada keterbukaan siswa, berbeda dengan penelitian ini yang berfokus pada prokrastinasi akademik.

Sementara itu, penelitian lain yang juga mengembangkan Solution Focused Brief Group Therapy (SFBGT) dapat digunakan untuk menurunkan perilaku agresif remaja (Baskoro, 2013). Penelitian tersebut memiliki intervensi psikologi yang menekankan kepada kelompok yang dinamis, sedangkan penelitian ini memiliki intervensi yang menekankan pada konseling individu. Akan tetapi masih samasama berfokus pada seolusi dalam penanganannya. Penelitian yang diteliti oleh Baskoro juga menggunakan desain penelitian tindakan (action reasearch) yang terdiri dari dua siklus, yaitu siklus pertama melibatan enam orang partisipan dan sikulus yang kedua juga melibatkan 6 orang partisipan.
Jumlah total partisipan yang dilibatkan sebanyak 12 orang dengan jenis kelamin lai-laki dan perempuan.

Akan tetapi penelitian ini menggunakann desain penelitian eksperimen dengan menggunakan bentuk desain one group pretest posttest design yang mana pada penelitia ini terdapat pretest sebelum diberikan perlakuan, dengan demikian hasil perlakuan dapat diketahui lebih akurat karena membandingkan dengan keadaan sebelum diberikan perlakuan melalui pretest posttest dan melibatkan tiga orang siswa perempuan.

Sependapat dengan penelitian sebelumnya yang menunjukan bahwa Solution Focused Brief Counseling (SFBC) dapat mengurangi prokrastinasi akademik siswa (Popowiranta, Widiastuti, \& Mahfud, 2019). Pada penelitian tersebut menggunakan bentuk desain penelitian randomized pretest posttest control group design, yang mana biasanya rancangan ini cukup sulit dilaksanakan di lapangan karena sulit atau tidak memungkinkan untuk melakukan randomisasi. Disamping itu hanya melakukan intervensi kepada satu kelompok saja, dan kelompok yang lain tidak di intervensi. Berbeda dengan penelitian ini menggunakan bentuk desain one group pretest posttest design yang melakukan satu kali pengukuran di tahap awal (pretest) sebelum adanya perlakuan (treatment) dan setelah diberikan perlakuan maka 
selanjutnya dilakukan pengukuran lagi (posttest). Hasil ini akan lebih akurat karena terdapat perbandingan antara sebelum dan sesudah diberikan treatment.

Berdasarkan beberapa penelitian sebelumnya yang menyatakan bahwa telah berhasil membuktikan efektivitas penggunaan solution focused brief counseling (SFBC) untuk mengatasi berbagai macam permasalahan. Dan penelitian ini juga membuktikan bahwa solution focused brief counseling (SFBC) telah terbukti efektif untuk menurunkan perilaku prokrastinasi akademik.

\section{SIMPULAN}

Setelah menyelesaikan penelitian dengan memperoleh hasil penilaian dan pengamatan yang sudah dilaksanakan oleh peneliti, dapat dilihat bahwa terdapat penurunan perilaku prorastinasi akademik siswa setelah diberikan treatment. Berdasarkan pada hasil perhitungan $t$-test diperoleh nilai $\mathrm{t}$ hitung $=5,959>2,919\left(\mathrm{t}_{\text {tabel }}\right)$ pada taraf signifikansi $(\alpha)=5 \%$ sehingga Ho ditolak yang menunjukan bahwa ada penurunan perilaku prokrastinasi akademik siswa yang signifikan setelah diberikan SFBC pada siswa kelas olahraga SMP Negeri 2 Galur Kulon Progo. Oleh karena itu, dapat disimpulkan bahwa penelitian SFBC efektif untuk menurunkan perilaku prokrastinasi akademik siswa kelas khusus olahraga SMP Negeri 2 Galur Kulon Progo.

Penggunaan SFBC dapat digunakan untuk menurunkan prokrastinasi akademik siswa kelas khusus olahraga SMP Negeri 2 Galur Kulon Progo yang menunjukkan adanya penurunan yang dapat dilihat dari hasil nilai pretest ke posttest. Hal ini juga dapat di gunakan sebagai salah satu intervensi yang dapat digunakan untuk guru BK.

\section{DAFTAR PUSTAKA}

Ackerman, D. S., \& Gross, B. L. (2005). My Instructor Made Me Do It: Task Characteristics Of Procrastination. Journal of Marketing Education, 27(1), 513.

Baskoro, D. S. B. (2013). Model Solution Focused Brief Group Therapy untuk Perilaku Agresif Remaja (Phd Thesis). University Of Muhammadiyah Malang.

Corey, G. (2015). Theory And Practice Of Counseling And Psychotherapy. Nelson Education.

Ernawati, E., \& Sumarwoto, V. D. (2016). Efektifitas Layanan Konseling Kelompok dengan Pendekatan Behavioral Melalui Teknik Shaping untuk Mengurangi Prokrastinasi Akademik Siswa Kelas VIII SMP Negerii 2 Barat Kabupaten Magetan. Counsellia: Jurnal Bimbingan Dan Konseling, 6(1), 41-53.

Fadila, N. (2015). Penerapan Solution Focused Brief 
Therapy (SFBT) untuk Meningkatkan Keterbukaan Diri pada Siswa Kelas VIII SMPN 1 Prambon. Jurnal BK UNESA, 5(3).

Fauziah, H. H. (2015). Fakor-Faktor yang Mempengaruhi Prokrastinasi Akademik pada Mahasiswa Fakultas Psikologi UIN Sunan Gunung Djati Bandung. Psympathic: Jurnal Ilmiah Psikologi, 2(2), 123132.

Fernando, F., \& Rahman, I. K. (2016). Konsep Bimbingan dan Konseling Islam Solution Focused Brief Therapy (SFBT) untuk Membantu Menyembuhkan Perilaku Prokrastinasi Mahasiswa. Jurnal Edukasi: Jurnal Bimbingan Konseling, 2(2), 215-236.

Fernando, F., \& Rahman, I. K. (2018). Efektifitas Solution Focused Brief Therapy (SFBT) Islami Guna Meningkatkan Regulasi Diri Mahasiswa yang Mengalami Prokrastinasi. Journal of Innovative Counseling: Theory, Practice, And Research, 2(02), 16-31.

Ferrari, J. R., Johnson, J. L., \& Mccown, W. G. (1995). Procrastination Research. Procrastination And Task Avoidance (Hlm. 21-46). Springer.

Ghufron, M. N., \& Risnawita, R. (2010). Teori-Teori Psikologi. Yogyakarta: Ar-Ruzz Media.

Knaus, W. J. (2002). The Procrastination Workbook: Your Personalized Program for Breaking Free From The
Patterns That Hold You Back. New Harbinger.

Munawaroh, M. L., Alhadi, S., \& Saputra, W. N. E. (2017). Tingkat Prokrastinasi Akademik Siswa Sekolah Menengah Pertama Muhammadiyah 9 Yogyakarta. Jurnal Kajian Bimbingan Dan Konseling, 2(1), 26-31.

Oematan, C. S. (2013). Hubungan Antara Prokrastinasi Akademik dan Prestasi Akademik pada Mahasiswa Fakultas PsikologiUniversitas Surabaya. Calyptra, 2(1), 1-7.

Popowiranta, A., Widiastuti, R., \& Mahfud, A. (2019). Penggunaan Solution Focused Brief Counseling (SFBC) untuk Mengurangi Prokrastinasi Akademik Siswa. ALIBKIN (Jurnal Bimbingan Konseling), $7(2)$.

Rusandi, M. A., \& Rachman, A. (2014). Efektifitas Konseling Singkat Berfokus Solusi (Solution Focused Brief Therapy) untuk Meningkatkan Self Esteem Mahasiswa Program Studi Bimbingan Konseling Fkip Unlam Banjarmasin. Al'Ulum, 62(4).

Saputra, W. N. E. (2015). Perbandingan Prokrastinasi Akademik Siswa SMK Melalui Penerapan Teknik Cognitive Restructuring Dan Cognitive Defusion. Disertasi Dan Tesis Program Pascasarjana UM.

Savithri, J. J. (2014). Interactive Effect Of Academic Procrastination and Academic Performance On Life Satisfaction. International 
Journal of Science And Research, 3(3), 377-381.

Senecal, C., Koestner, R., \& Vallerand, R. J. (1995). SelfRegulation And Academic Procrastination. The Journal Of Social Psychology, 135(5), 607-619.

Solomon, L. J., \& Rothblum, E. D. (1984). Academic Procrastination: Frequency and Cognitive-Behavioral

Correlates. Journal of Counseling Psychology, 31(4), 503.

Sumarwiyah, S., Zamroni, E., \& Hidayati, R. (2015). Solution Focused Brief Counseling (SFBC): Alternatif Pendekatan dalam Konseling Keluarga. Jurnal Konseling Gusjigang, 1(2).

Wiyono, B. D. (2015). Keefektifan Solution-Focused Brief Group Counseling untuk Meningkatkan Motivasi Berprestasi Siswa Sekolah Menengah Kejuruan. JKI (Jurnal Konseling Indonesia), 1(1), 29-37.

Yusak, M. (2014). Korelasi Religiusitas dengan Prestasi Akademik. Jurnal Intelegensia, 3(1). 